medRxiv preprint doi: https://doi.org/10.1101/2020.06.08.20119636; this version posted August 7, 2020. The copyright holder for this preprint (which was not certified by peer review) is the author/funder, who has granted medRxiv a license to display the preprint in It is made available under a CC-BY-NC-ND 4.0 International license .

\title{
No Evidence for Reduced Hospital Admissions or Increased Deaths from Stroke or Heart Attack During COVID-19
}

Katharine Reeves, Samuel Watson, Tanya Pankhurst, Kamlesh Khunti, Suzy Gallier, Magdalena Skrybant, Peter J Chilton, Richard J Lilford*

Katharine Reeves, Statistical Intelligence Analyst (Informatics), University Hospitals Birmingham NHS Foundation Trust, Katharine.Reeves@uhb.nhs.uk

Samuel Watson, Associate Professor, University of Warwick, s.watson.1@warwick.ac.uk

Tanya Pankhurst, Consultant Nephrologist, University Hospitals Birmingham NHS Foundation Trust, Tanya.Pankhurst@uhb.nhs.uk

Kamlesh Khunti, Professor of Primary Care Diabetes \& Vascular Medicine, University of Leicester, kk22@le.ac.uk

Suzy Gallier, Head of Informatics Research \& Commercial Development, University Hospitals Birmingham NHS Foundation Trust; and Head of Bio-Informatics, PIONEER: HDR-UK hub in Acute care, Suzy.Gallier@uhb.nhs.uk

Magdalena Skrybant, Patient and Public Involvement \& Engagement Lead, University of Birmingham, M.T.Skrybant@bham.ac.uk

Peter J Chilton, Research Fellow, University of Birmingham, p.j.chilton@bham.ac.uk

Richard J Lilford (0000-0002-0634-984X), Professor of Clinical Health, University of Birmingham,

r.j.lilford@bham.ac.uk

* Corresponding Author: Richard J Lilford, Murray Learning Centre, University of Birmingham, Edgbaston B15 2TT, United Kingdom r.j.lilford@bham.ac.uk @rjlilford

The authors declare no conflicts of interest.

NOTE: This preprint reports new research that has not been certified by peer review and should not be used to guide clinical practice. 
medRxiv preprint doi: https://doi.org/10.1101/2020.06.08.20119636; this version posted August 7, 2020. The copyright holder for this preprint (which was not certified by peer review) is the author/funder, who has granted medRxiv a license to display the preprint in It is made available under a CC-BY-NC-ND 4.0 International license .

Claims that hospital admissions for heart attack and stroke have declined over the COVID-19 pandemic have been made in at least 16 newspaper articles in the UK (Table 1). In contrast, data from the West Midlands Ambulance Service (WMAS) have not reported any reduction in call-outs for patients with stroke or ST-Elevation Myocardial Infarction (STEMI). ${ }^{1}$ However, not all admissions with these diseases arrive via the Accident and Emergency (A\&E) department. Furthermore, a study from Italy showed around a 30\% reduction in acute coronary syndrome related hospital admission during the COVID-19 crisis. $^{2}$ We therefore examined admissions to University Hospitals Birmingham NHS Foundation Trust, which is the UK's largest hospital group and lies within the WMAS footprint. We examined cases admitted with STEMI (Codes I21.0 to I21.3 and I21.9) and stroke (Codes I61.0 to 161.9 and I63.0 to 163.9 ) from week 1 of 2016 to week 17 of 2019 and compared to the same period in 2020 pre and post lockdown. We examined three end-points: total admissions, admissions from $A \& E$, and seven-day in-hospital mortality. The figure shows the number of admissions over time and proportionate differences from the 2016-2019 average. Small reductions in weekly admissions were observed for STEMI $(-4 \cdot 2,95 \% \mathrm{Cl}[-10 \cdot 6,2 \cdot 1], \mathrm{p}=0 \cdot 17)$ and stroke $(-4 \cdot 4[-10 \cdot 8,2 \cdot 0], \mathrm{p}=0 \cdot 15)$, but there was little evidence that this represents a shift in the overall mean in the post-lockdown period. We found little evidence of a difference in the number of patients being admitted through the emergency department (STEMI: $-3 \cdot 6$ percentage points [pp], $95 \% \mathrm{Cl}[2 \cdot 1,-9 \cdot 3], p=0 \cdot 19$; stroke: $-5 \cdot 0$ pp, 95\% Cl [1·7, -11·7], p=0·19) or seven-day in-hospital mortality (STEMI: $-0 \cdot 0$ pp, $95 \% \mathrm{Cl}[1 \cdot 4,-1 \cdot 4]$, $p=1 \cdot 00$; stroke: $-1.6 \mathrm{pp}, 95 \% \mathrm{Cl}[1 \cdot 1,-4 \cdot 3], \mathrm{p}=0 \cdot 21)$. Examination of the long run series in the Figure shows that there were larger spikes and troughs over the entire observation period, than those observed after lockdown occurred.

In summary, despite reported media claims of reduction in emergency cardiovascular hospital admissions, we did not observe any evidence of a reduction in admissions with these conditions. We argue that evidence on admission rates should be presented over time as well as statistically. We cannot exclude a modest effect of COVID-19 on admission rates for the serious and treatable emergency conditions studied here. 
medRxiv preprint doi: https://doi.org/10.1101/2020.06.08.20119636; this version posted August 7, 2020. The copyright holder for this preprint (which was not certified by peer review) is the author/funder, who has granted medRxiv a license to display the preprint in

It is made available under a CC-BY-NC-ND 4.0 International license .

Figure 1.

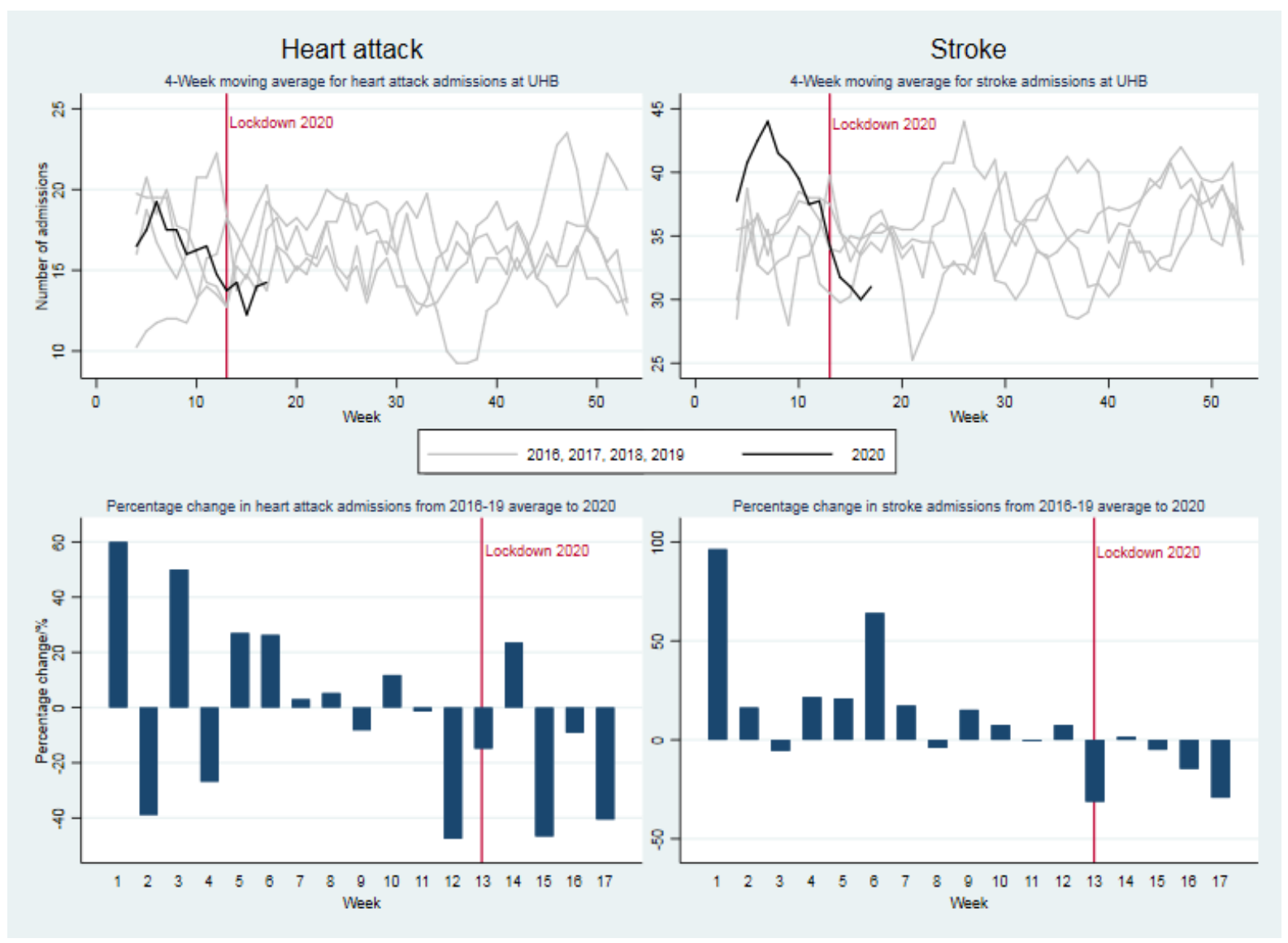

Top panel: 4-week moving average of weekly admissions for heart attack (left) and Stroke (right).

Bottom panel: Percentage change from 2016-2019 average number of admissions to 2020 number of admissions for heart attack (left) and stroke (right).

The start of the lockdown period in the United Kingdom is shown by a red line at week $13(23 / 04 / 20)$. 
medRxiv preprint doi: https://doi.org/10.1101/2020.06.08.20119636; this version posted August 7, 2020. The copyright holder for this preprint (which was not certified by peer review) is the author/funder, who has granted medRxiv a license to display the preprint in It is made available under a CC-BY-NC-ND 4.0 International license .

\section{References:}

1. Lumley-Holmes J, Brake S, Docherty M, Lilford R, Watson S. Emergency ambulance services for heart attack and stroke during UK's COVID-19 lockdown. Lancet. 2020. DOI: 10.1016/S0140-6736(20)31031-X.

2. De Filippo O, D'Ascenzo F, Angelini F, et al. Reduced Rate of Hospital Admissions for ACS during Covid-19 Outbreak in Northern Italy. N Engl J Med. 2020. DOI: 10.1056/NEJMc2009166.

\section{Acknowledgements:}

This work uses data provided by patients and collected by the NHS as part of their care and support at University Hospitals Birmingham NHS Foundation Trust. It has been approved by University Hospitals Birmingham NHS Foundation Trust, Clinical Audit Registration \& Management System and the COVID-19 research facilitation group under application reference [16049].

\section{Funding Source:}

This study was funded by the National Institute for Health Research (NIHR) Applied Research Collaboration (ARC) West Midlands and NIHR ARC East Midlands. Views expressed are not necessarily those of the NHS, the NIHR or the Department of Health and Social Care. 
Table 1. Newspaper reports on declining access to hospital care for stroke and heart attack

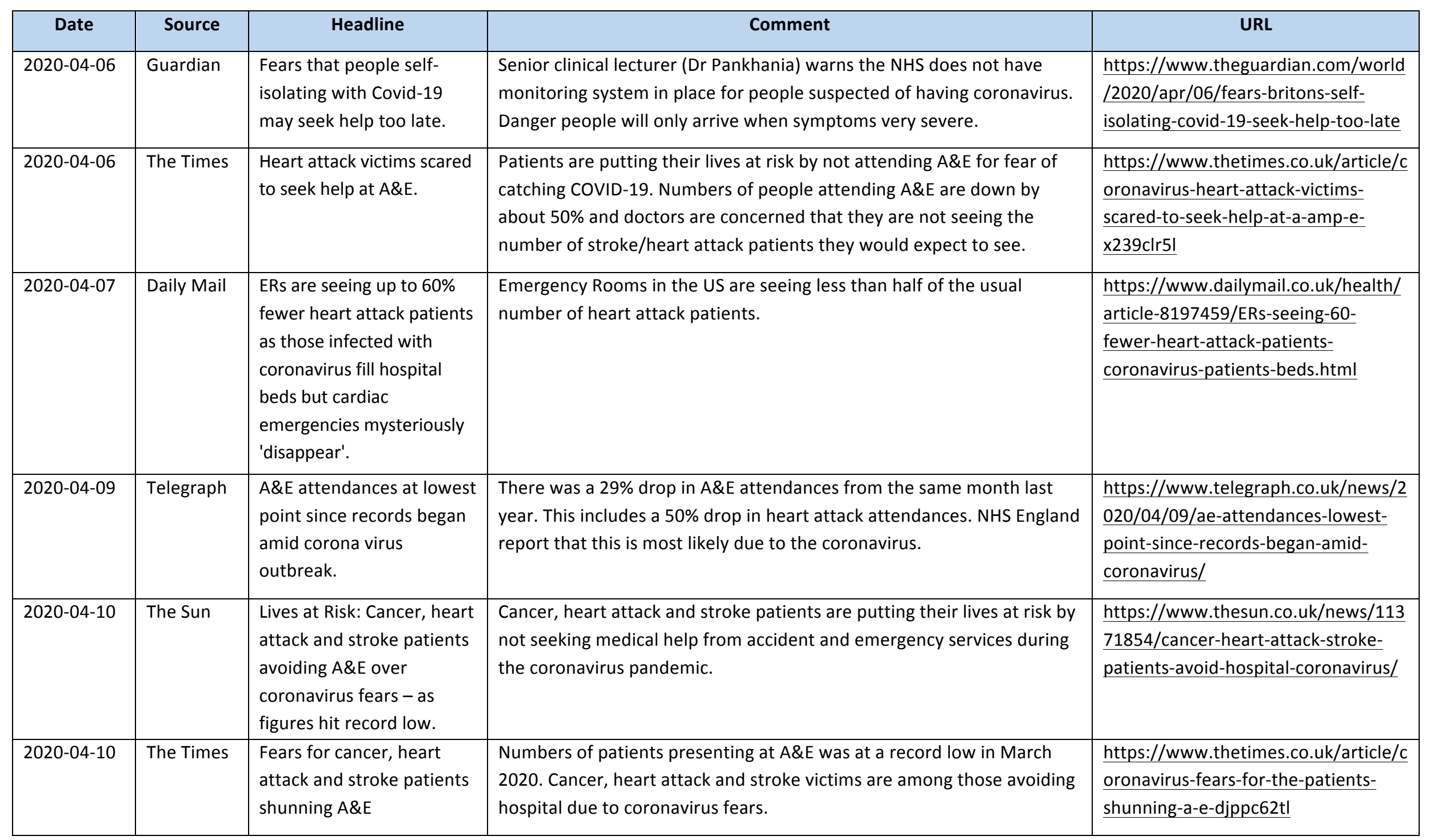




\begin{tabular}{|c|c|c|c|c|}
\hline 2020-04-16 & Guardian & $\begin{array}{l}\text { Warning as UK coronavirus } \\
\text { outbreak leads to sharp } \\
\text { rise in deaths at home }\end{array}$ & $\begin{array}{l}\text { Minutes from a remote meeting held by London A\&E chiefs reveal that } \\
\text { people are reluctant to call an ambulance when they need it during the } \\
\text { coronavirus pandemic. This has led to a sharp rise in seriously ill people } \\
\text { dying at home. This includes people dying from cardiac arrest. }\end{array}$ & $\begin{array}{l}\text { https://www.theguardian.com/societ } \\
\text { y/2020/apr/15/sharp-rise-in-ill- } \\
\text { patients-dying-at-home-since- } \\
\text { coronavirus-outbreak }\end{array}$ \\
\hline $2020-04-16$ & Guardian & $\begin{array}{l}\text { Concern as heart and } \\
\text { stroke patients delay } \\
\text { seeking help }\end{array}$ & $\begin{array}{l}\text { President of the Royal College of Physicians (Andrew Goddard) states } \\
\text { that consultants in cardiology and emergency medicine report a drop in } \\
\text { patients presenting with heart attack symptoms. The Association of } \\
\text { British Neurologists' stroke advisory group (David Werring) reported a } \\
\text { reduction in people being referred with stroke or treated for stroke as } \\
\text { the same time last year. }\end{array}$ & $\begin{array}{l}\text { https://www.theguardian.com/world } \\
\text { /2020/apr/16/coronavirus-concern- } \\
\text { heart-attack-stroke-patients-delay- } \\
\text { seeking-help }\end{array}$ \\
\hline 2020-04-16 & Daily Mail & $\begin{array}{l}\text { Coronavirus crisis has } \\
\text { caused a spike in the } \\
\text { number of Britons dying } \\
\text { from cardiac arrests at } \\
\text { home because people are } \\
\text { 'too scared to call } 999 \text { in } \\
\text { case they catch the disease } \\
\text { in hospital' }\end{array}$ & $\begin{array}{l}\text { People who are seriously ill are delaying calling the emergency services } \\
\text { due to fear of getting the coronavirus in hospital or fear of } \\
\text { overburdening the system. As a consequence, people are dying in their } \\
\text { own homes. }\end{array}$ & $\begin{array}{l}\text { https://www.dailymail.co.uk/news/ar } \\
\text { ticle-8224797/Coronavirus-crisis- } \\
\text { causes-spike-number-Britons-dying- } \\
\text { home.html }\end{array}$ \\
\hline 2020-04-17 & BBC News & $\begin{array}{l}\text { Non-virus patients 'at risk' } \\
\text { over hospital avoidance }\end{array}$ & $\begin{array}{l}\text { People in Yorkshire put their health at risk due to not seeing help when } \\
\text { they need it due to fears of getting coronavirus or of overloading the } \\
\text { healthcare system. Since the start of the crisis, the number of potential } \\
\text { heart attack and stroke sufferers seen by medics in Sheffield has halved. }\end{array}$ & $\begin{array}{l}\text { https://www.bbc.co.uk/news/uk- } \\
\text { england-52323908 }\end{array}$ \\
\hline $\begin{array}{l}2020-04- \\
20\end{array}$ & BBC News & $\begin{array}{l}\text { Coronavirus: Over } 300 \\
\text { patients refuse ambulance } \\
\text { over Covid-19 fears }\end{array}$ & $\begin{array}{l}\text { A health chief (Toby Lewis) said that patients with severe illnesses } \\
\text { refuse to be taken to hospital by ambulance due to fears over } \\
\text { coronavirus. }\end{array}$ & $\begin{array}{l}\text { https://www.bbc.co.uk/news/uk- } \\
\text { england-birmingham-52412394 }\end{array}$ \\
\hline $2020-04-22$ & Daily Mail & $\begin{array}{l}\text { Heart attack and stroke } \\
\text { victims have to wait more } \\
\text { than TWO HOURS for an } \\
\text { ambulance as coronavirus }\end{array}$ & $\begin{array}{l}\text { Emergency response times are the 'worst on record' during the } \\
\text { coronavirus due to a surge in demand and call outs due to coronavirus } \\
\text { and many paramedics off sick. Patients with heart attacks and stroke } \\
\text { face a response time of } 2 \mathrm{~h} 20 \text { minutes. They should have a response }\end{array}$ & $\begin{array}{l}\text { https://www.dailymail.co.uk/news/ar } \\
\text { ticle-8246947/Heart-attack-stroke- } \\
\text { victims-wait-TWO-HOURS- } \\
\text { ambulance.html }\end{array}$ \\
\hline
\end{tabular}




\begin{tabular}{|c|c|c|c|c|}
\hline & & $\begin{array}{l}\text { crisis starts to squeeze } \\
\text { front line services. }\end{array}$ & $\begin{array}{l}\text { time of } 18 \text { minutes. The delayed response time increases risks for } \\
\text { patients. }\end{array}$ & \\
\hline 2020-04-25 & Mirror & $\begin{array}{l}\text { NHS boss pleads for public } \\
\text { to get medical care for } \\
\text { non-coronavirus illnesses. }\end{array}$ & $\begin{array}{l}\text { NHS England's medical director (Stephen Powis) urged patients to seek } \\
\text { help without delay as A\&E attendances drop. This includes patients with } \\
\text { symptoms of stroke or chest pain. }\end{array}$ & $\begin{array}{l}\text { https://www.mirror.co.uk/news/uk- } \\
\text { news/nhs-boss-pleas-public-medical- } \\
\underline{21925020}\end{array}$ \\
\hline $2020-04-25$ & BBC News & $\begin{array}{l}\text { Coronavirus: Plea for } \\
\text { Public to get help when } \\
\text { they need it. }\end{array}$ & $\begin{array}{l}\text { Doctors and healthcare workers advise people to get help when they } \\
\text { need it. Delays in seeking help could put their long-term health, as well } \\
\text { as their life, at risk. }\end{array}$ & $\begin{array}{l}\text { https://www.bbc.co.uk/news/health- } \\
\text { 52417599 }\end{array}$ \\
\hline $2020-04-27$ & BBC News & $\begin{array}{l}\text { Coronavirus: Royal } \\
\text { Papworth reports } \\
\text { admissions 'down } 50 \% \text { ' at } \\
\text { heart and lung hospital. }\end{array}$ & $\begin{array}{l}\text { Doctors at the Royal Papworth hospital report that heart attack and } \\
\text { cancer admissions have more than halved during the coronavirus } \\
\text { pandemic. Patients may be avoiding hospital for fear of contracting } \\
\text { COVID-19 or putting pressure on the NHS. }\end{array}$ & $\begin{array}{l}\text { https://www.bbc.co.uk/news/uk- } \\
\text { england-cambridgeshire-52445067 }\end{array}$ \\
\hline
\end{tabular}

